\title{
Hubungan Tingkat Pengetahuan dan Sikap Santri Terhadap Kesiapsiagaan dalam Penanggulangan Bencana Kebakaran di Pondok Pesantren X di Kota Surabaya
}

\author{
Friska Ayu, Ratna Ayu Ratriwardhani \\ Universitas Nahdlatul Ulama Surabaya \\ e-mail: friskayuligoy@unusa.ac.id
}

\begin{abstract}
Preparedness is a part of the disaster management process which aims to prevent and minimize disaster risk which is pro-active before a disaster occurs. Fire disasters can occur anywhere, including in the Islamic boarding schools, this is because in the Islamic boarding schools there is not only a teaching and learning process, but there are additional activities such as fulfilling their daily needs such as the students also live in the cottage during their studies. This research was conducted in July-August 2020 which aims to analyze the relationship between the level of knowledge and attitudes of students towards fire disaster preparedness at Islamic Boarding School Pondok Karya at Manado City. Type of this research using analytic survey with a cross sectional approach, with a total sample of 89 people was taken using accidental techniques. The results of this study showed that as many as 60 students (67.4\%) have a level of preparedness that is ready to cope with fire disasters with a good level of knowledge (47.2\%) on fire management procedures although only 33 students (37.1\%) knew how to use fire extinguisher. Statistical test result using chi square test show that there is a relationship between the level of knowledge (0.002) and attitude (0.000) with the level of preparedness in fire disaster preparedness at Islamic Boarding School Pondok Karya at Manado City. Recommended for Islamic Boarding School Management are required to provide education on fire disaster management preparedness to students at least once a year, so that if a fire disaster occurs, the risk can be minimized.
\end{abstract}

Keywords: fire disaster preparedness, Islamic boarding school, santri SIGAB

\section{PENDAHULUAN}

Penyelenggaraan pendidikan dan keselamatan kerja di lembaga pendidikan masih perlu mendapatkan perhatian yang lebih intensif. Sebuah lembaga pendidikan tidak berbeda jauh dengan sebuah perusahaan, di dalam lembaga pendidikan terdapat tenaga kerja, orang-orang selain pekerja, risiko bahaya, sumber bahaya, dan risiko terjadinya bahaya. Berbeda dengan lembaga pendidikan kegiatan di sebuah perusahaan terfokus pada kegiatan produksi, namun demikian bukan berarti lembaga pendidikan tidak mempunyai risiko bahaya. Salah satu risiko bahaya yang dapat terjadi di lembaga pendidikan adalah bencana kebakaran.
Kejadian kebakaran di lingkungan pendidikan seperti kampus pernah terjadi di kampus STIE (Sekolah Tinggi Ilmu Ekonomi) Perbanas di kawasan Kuningan Jakarta dan Gedung Dekanat Fakultas Teknik Universitas Indonesia Depok Jawa Barat pada tahun 2001[3]. Pada bulan Maret 2019 telah terjadi kebakaran di Ruang Kemahasiswaan Fakultas Kesehatan Masyarakat Universitas Airlangga Surabaya, penyebab kebakaran diduga karena adanya hubungan pendek arus listrik. Kejadian kebakaran di lingkungan pondok pesantren pernah terjadi di Malaysia tahun 2017 yang menewaskan 24 orang santri dan pengurus pondok pesantren, adapun penyebab kebakaran adalah hubungan arus pendek listrik. 
Pondok pesantren merupakan salah satu lembaga pendidikan yang mempunyai risiko bahaya, karena di dalam kegiatannya selalu menggunakan alat dan bahan untuk menunjang proses belajar mengajar dan sumber energi yang mampu menimbulkan bahaya. Sumber energi seperti listrik, gas elpiji, dan bahan-bahan kimia jika tidak ditata dengan baik dapat menimbulkan risiko kebakaran. Kebakaran merupakan bencana yang paling sering dihadapi dan bisa digolongkan sebagai bencana alam ataupun bencana yang disebabkan oleh perbuatan manusia. Bahaya kebakaran dapat terjadi setiap saat dan sewaktuwaktu, yang banyak mengakibatkan kerugian berupa materi, lingkungan, finansial, peralatan, dan manusia itu sendiri [4].

Faktor utama yang dapat mengakibatkan bencana tersebut menimbulkan korban dan kerugian besar, yaitu kurangnya pemahaman tentang karakteristik bahaya, sikap, atau perilaku yang mengakibatkan penurunan sumber daya alam, kurangnya informasi peringatan dini yang mengakibatkan ketidaksiapan, dan ketidakberdayaan atau ketidakmampuan dalam menghadapi bencana. Kesiapsiagaan dikelompokkan menjadi empat parameter yaitu pengetahuan dan sikap, perencanaan kedaruratan, sistem peringatan dan mobilisasi sumber daya. Oleh karena itu, kegiatan penelitian ini perlu dilaksanakan untuk melihat hubungan antara tingkat pengetahuan dan sikap santri terhadap kesiapsiagaan penanggulangan bencana kebakaran di pondok pesantren.

\section{METODE PENELITIAN}

Penelitian ini pada awalnya akan di lakukan di sebuah pondok pesantren yang berada di Kota Surabaya, survei awal dan perizinan telah dilakukan oleh tim, namun dikarenakan adanya pandemic Covid-19 yang melanda Indonesia ma- ka pondok pesantren tempat penelitian yang dituju belum dapat kembali ke aktivitas normal, dengan alasan tersebut maka tim peneliti memindahkan lokasi penelitian ke pondok pesantren yang berada di Kota Manado, alasan pemilihan tempat penelitian ini adalah lokasi domisili peneliti selama masa pandemi berada di Kota Manado, selain itu para santri masih tetap tinggal di pondok selama masa pandemic. Kegiatan penelitian ini dilaksanakan di Pesantren Lembaga Pendidikan Islam, Pondok Karya Pembangunan Kota Manado di Jalan Arie Lasut Kelurahan Kombos Timur, Kecamatan Singkil Manado, Sulawesi Utara.

Jenis penelitian yang digunakan dalam penelitian ini adalah survei analitik dengan rancangan cross sectional study yakni suatu rancangan penelitian yang mempelajari hubungan variabel independen/variabel bebas dalam hal ini tingkat pengetahuan dan sikap santri dengan variabel dependen/variabel terikat yakni kesiapsiagaan dalam penanggulangan bencana kebakaran di pondok pesantren. Populasi dalam penelitian ini adalah seluruh santri yang tinggal di pondok pesantren sebanyak 164 orang. Besar sampel yang akan diambil sebanyak 89 orang yang diambil menggunakan teknik accidental sampling.

\section{HASIL DAN PEMBAHASAN}

\section{A. Hasil Penelitian}

Data Tabel 1 menunjukkan distribusi karakteristik santri yang menjadi responden dalam penelitian ini. Sebagian besar santri berusia 1015 tahun (85.4\%) dengan pendidikan terakhir adalah SMP yakni sebanyak 38 orang. Tingkat pengetahuan santri akan tata cara penanggulangan bencana kebakaran termasuk dalam kategori cukup baik (52.8\%), meskipun hanya 33 orang yang tahu menggunakan alat pemadam api ringan 
Friska Ayu, Ratna Ayu Ratriwardhani, Hubungan Tingkat Pengetahuan dan Sikap Santri Terhadap Kesiapsiagaan dalam Penanggulangan Bencana Kebakaran di Pondok Pesantren X di Kota Surabaya

Tabel 1 Distribusi Karakteristik Santri di Pesantren Lembaga Pendidikan Islam, Pondok Karya Pembangunan, Kota Manado Tahun 2020

\begin{tabular}{|c|c|c|c|}
\hline \multicolumn{2}{|c|}{ Karakteristik Responden } & n & $\%$ \\
\hline \multirow[t]{3}{*}{ Umur } & 10-15 Tahun & 76 & 85,4 \\
\hline & 16-20 Tahun & 12 & 13,5 \\
\hline & $>20$ Tahun & 1 & 1,1 \\
\hline \multirow{3}{*}{$\begin{array}{l}\text { Lama Tinggal di } \\
\text { Pondok }\end{array}$} & $<1$ Tahun & 51 & 57,3 \\
\hline & 1-2 Tahun & 24 & 27,0 \\
\hline & $>2$ Tahun & 14 & 15,7 \\
\hline \multirow[t]{4}{*}{ Pendidikan Terakhir } & $\begin{array}{l}\text { Madrasah Ibtidaiyah } \\
\text { (SD) }\end{array}$ & 37 & 41,6 \\
\hline & $\begin{array}{l}\text { Madrasah Tsanawiyah } \\
\text { (SMP) }\end{array}$ & 38 & 42,7 \\
\hline & $\begin{array}{l}\text { Madrasah Aliyah } \\
\text { (SMA) }\end{array}$ & 12 & 13,5 \\
\hline & PT (D4/S1) & 2 & 2,2 \\
\hline \multirow{2}{*}{$\begin{array}{l}\text { Pengalaman } \\
\text { Menghadapi } \\
\text { Kebakaran }\end{array}$} & $\mathrm{Ya}$ & 9 & 10,1 \\
\hline & Tidak & 80 & 89,9 \\
\hline \multirow[t]{2}{*}{ Tingkat Pengetahuan } & Cukup Baik & 47 & 52,8 \\
\hline & Baik & 42 & 47,2 \\
\hline \multirow[t]{2}{*}{ Sikap } & Sikap Negatif & 26 & 29,2 \\
\hline & Sikap Positif & 63 & 70,8 \\
\hline \multirow{2}{*}{$\begin{array}{l}\text { Pemanfaatan Sarpra } \\
\text { Penanggulangan } \\
\text { Kebakaran }\end{array}$} & $\begin{array}{l}\text { Tersedia tetapi tidak } \\
\text { tahu menggunakan }\end{array}$ & 56 & 62,9 \\
\hline & $\begin{array}{l}\text { Tersedia dan tahu } \\
\text { menggunakan }\end{array}$ & 33 & 37,1 \\
\hline \multirow{2}{*}{$\begin{array}{l}\text { Tingkat } \\
\text { Kesiapsiagaan } \\
\text { Bencana Kebakaran }\end{array}$} & Kurang Siap & 29 & 32,6 \\
\hline & Siap & 60 & 67,4 \\
\hline Jumlah & & 89 & 100,0 \\
\hline
\end{tabular}

Tabel 2 Uji Hubungan antara Tingkat Pengetahuan dan Sikap Santri terhadap Kesiapsiagaan dalam Penanggulangan Bencana Kebakaran di Pesantren Lembaga Pendidikan Islam, Pondok Karya Pembangunan, Kota Manado Tahun 2020

\begin{tabular}{|c|c|c|c|c|c|c|}
\hline \multirow{3}{*}{ Variabel } & & \multicolumn{4}{|c|}{$\begin{array}{c}\text { Variabel Terikat } \\
\text { (Kategori Kesiapsiagaan } \\
\text { Bencana Kebakaran) }\end{array}$} & \multirow{3}{*}{ P-value } \\
\hline & Bebas & \multicolumn{2}{|c|}{$\begin{array}{c}\text { Kurang } \\
\text { Siap }\end{array}$} & \multicolumn{2}{|c|}{ Siap } & \\
\hline & & $\mathbf{n}$ & $\%$ & n & $\%$ & \\
\hline \multirow{2}{*}{$\begin{array}{l}\text { Tingkat } \\
\text { Pengetahu } \\
\text { an }\end{array}$} & $\begin{array}{l}\text { Cukup } \\
\text { Baik }\end{array}$ & 24 & 75.0 & 23 & 40.4 & \multirow{3}{*}{0.002} \\
\hline & Baik & 8 & 25.0 & 34 & 59.6 & \\
\hline Jumlah & & 32 & 100 & 57 & 100 & \\
\hline \multirow[t]{2}{*}{$\begin{array}{l}\text { Sikap } \\
\text { Santri }\end{array}$} & $\begin{array}{l}\text { Sikap } \\
\text { Negatif }\end{array}$ & 23 & 79.3 & 3 & 5.0 & \multirow{3}{*}{0.000} \\
\hline & $\begin{array}{l}\text { Sikap } \\
\text { Positif }\end{array}$ & 6 & 20.7 & 57 & 95.0 & \\
\hline Jumlah & & 29 & 100 & 60 & 100 & \\
\hline
\end{tabular}

(APAR), sedangkan sikap santri dalam menghadapi bencana kebakaran dalam kategori positif (70.8\%). Tingkat kesiapsiagaan santri dalam penanggulangan bencana kebakaran berada dalam kategori siap (67.4\%).

Data Tabel 2 menunjukkan hasil uji statistik dengan menggunakan uji chi square terhadap variabel bebas dengan variabel terikat menunjukkan bahwa terdapat hubungan antara tingkat pengetahuan (0.002) dan sikap (0.000) dengan tingkat kesiapsiagaan dalam penanggulangan bencana kebakaran di Pesantren Lembaga Pendidikan Islam, Pondok Karya Pembangunan, Kota Manado. Pengetahuan merupakan faktor utama dan menjadi kunci untuk kesiapsiagaan. Pengetahuan yang dimiliki biasanya dapat memengaruhi sikap dan kepedulian untuk siap siaga dalam mengantisipasi bencana.

\section{B. Pembahasan}

Kejadian kebakaran di lingkungan pendidikan seperti kampus pernah terjadi di kampus STIE (Sekolah Tinggi Ilmu Ekonomi) Perbanas di kawasan Kuningan Jakarta dan Gedung Dekanat Fakultas Teknik Universitas Indonesia Depok Jawa Barat pada tahun 2001 [3] Pada bulan Maret 2019 telah terjadi kebakaran di Ruang Kemahasiswaan Fakultas Kesehatan Masyarakat Universitas Airlangga Surabaya, penyebab kebakaran diduga karena adanya hubungan pendek arus listrik. Kejadian kebakaran di lingkungan pondok pesantren pernah terjadi di Malaysia Tahun 2017 yang menewaskan 24 orang santri dan pengurus pondok pesantren, adapun penyebab kebakaran adalah hubungan arus pendek listrik.

Faktor utama yang dapat mengakibatkan bencana tersebut menimbulkan korban dan kerugian besar, yaitu kurangnya pemahaman tentang 
karakteristik bahaya, sikap, atau perilaku yang mengakibatkan penurunan sumber daya alam, kurangnya informasi peringatan dini yang mengakibatkan ketidaksiapan, dan ketidakberdayaan atau ketidakmampuan dalam menghadapi bencana. Kesiapsiagaan dikelompokkan menjadi empat parameter yaitu pengetahuan dan sikap, perencanaan kedaruratan, sistem peringatan, dan mobilisasi sumber daya.

Dalam penelitian ini pengetahuan yang harus dimiliki santri mengenai bencana kebakaran yaitu pengetahuan dan pemahaman tentang penyebab kebakaran dan kesiapsiagaan menghadapi bencana kebakaran yang meliputi pemahaman mengenai tindakan penyelamatan diri yang tepat saat terjadi kebakaran serta tindakan dan peralatan yang perlu disiapkan sebelum terjadi kebakaran, demikian juga sikap dan kepedulian terhadap faktor risiko kebakaran. Pengetahuan merupakan faktor utama dan menjadi kunci untuk kesiapsiagaan. Pengetahuan yang dimiliki biasanya dapat memengaruhi sikap dan kepedulian untuk siap siaga dalam mengantisipasi bencana.

Pada penelitian ini dapat dilihat bahwa sebagian besar santri di Pesantren Lembaga Pendidikan Islam, Pondok Karya Pembangunan, Kota Manado menunjukkan tingkat pengetahuan dalam penanganan bencana kebakaran berada dalam kategori cukup, hal ini berarti para santri cukup mengetahui dan memahami penyebab bencana kebakaran, mengetahui cara penyelamatan diri ketika terjadi bencana, dan memahami tindakan yang akan dilakukan ketika terjadi bencana kebakaran.

Dalam penelitian ini sikap merupakan salah satu faktor yang berhubungan dengan tindakan kesiapsiagaan dalam penanggulangan bencana kebakaran. Sikap santri di pondok pesantren ini menunjukkan sikap yang tanggap darurat terhadap bencana kebakaran, beberapa santri menge- tahui jalur evakuasi dan letak alat pemadam api ringan (APAR) namun beberapa santri masih belum tahu menggunakan alat pemadam api ringan tersebut.

Hasil penelitian ini didukung oleh Lenawida (2011) yang mengatakan bahwa variabel sikap merupakan faktor yang paling dominan memengaruhi kesiapsiagaan rumah tangga dalam menghadapi bencana gempa bumi. Penelitian LIPI-UNESCO/ISDR (2006) tentang kesiapsiagaan masyarakat pedesaan Aceh menghadapi bencana, menunjukkan bahwa pengetahuan mempunyai pengaruh terhadap tingkat kesiapsiagaan menghadapi bencana pada masyarakat pedesaan Aceh.

LIPI-UNESCO/ISDR (2006) juga menjelaskan bahwa pengetahuan merupakan faktor utama kunci kesiapsiagaan. Upaya meningkatkan pengetahuan melalui pendidikan kebencanaan diharapkan dapat meningkatkan perilaku kesiapsiagaan seseorang. Hal ini dapat dilihat dari hasil penelitian di mana pengetahuan yang semakin baik dapat meningkatkan perilaku kesiapsiagaan seseorang.

\section{KESIMPULAN DAN SARAN}

Kesimpulan dari kegiatan penelitian ini bahwa terdapat hubungan antara tingkat pengetahuan dan sikap santri terhadap kesiapsiagaan penanggulangan bencana kebakaran di pondok pesantren. Terdapat empat parameter yang dapat diukur untuk melihat kesiapsiagaan seseorang terhadap bencana yakni pengetahuan akan potensi bahaya tersebut, sikap, perencanaan kedaruratan, sistem peringatan, dan mobilisasi sumber daya saat terjadi bencana. Oleh karena itu, disarankan bagi pengurus pesantren dapat memberikan edukasi kesiapsiagaan penanggulangan bencana kebakaran kepada santri minimal seta- 
Friska Ayu, Ratna Ayu Ratriwardhani, Hubungan Tingkat Pengetahuan dan Sikap Santri Terhadap Kesiapsiagaan dalam Penanggulangan Bencana Kebakaran di Pondok Pesantren X di Kota Surabaya

hun sekali sehingga jika terjadi bencana kebakaran maka risiko dapat diminimalisasi.

\section{REFERENSI}

Bakornas PB. 2007. Pengenalan Karakteristik Bencana dan Upaya Mitigasinya di Indonesia. Jakarta: Badan Nasional Penanggulangan Bencana.

Badan Nasional Penanggulangan Bencana. 2012. Data Kebencanaan (diakses melalui www. bnpb.go.id diakses pada tanggal 27 September 2017).

Depnakertrans. Materi Evaluasi dan Penunjukan Calon Abli K3:Pengawasan K3 Penanggulangan Kebakaran. Jakarta.

Fitriana, L., Suroto, \& Kurniawan, B. 2017. Faktor-faktor yang Berhubungan dengan Upaya Kesiapsiagaan Karyawan Bagian Produksi dalam Menghadapi Bahaya Kebakaran di PT Sandang Asia Maju Abadi. Jurnal Kesehatan Masyarakat (e-Journal), 5(3), 295-307.

International Fire Service Training Association (IFSTA). 2007. Dasar-Dasar Penanggulangan Kebakaran (Essential of Fire Fighting). Dinas Kebakaran. DKI Jakarta.

Kementerian Dalam Negeri. 2007. Peraturan Menteri Dalam Negeri Nomor 27 Tahun 2007 tentang Pedoman Penyiapan Sarana dan Prasarana dalam Penanggulangan bencana. Jakarta.

Kodoatie, J.R. 2006. Pengelolaan Bencana Terpadu. Jakarta: Yarsif Watampone.
Miranti, R.S. \& Mardiana. 2018. Penerapan Sistem Proteksi Aktif dan Sarana Penyelamatan Jiwa sebagai Upaya Pencegahan Kebakaran. Journal of Public Healts, 2(1), 23-32.

Pangesti, Asih Dwi Hayu. 2012. Gambaran Tingkat Pengetahuan dan Aplikasi Kesiapan Bencana pada Mahasiswa Fakultas Ilmu Keperawatan Universitas Indonesia Tahun 2012. Tidak diterbitkan. Skripsi. Fakultas Ilmu Keperawatan Universitas Indonesia. Patuju, A. 2018. Hubungan Sikap terhadap Resiko Bencana Kebakaran dengan Kesiapsiagaan Menghadapi Kebakaran di Pemukiman Kelurahan Air Putih Kecamatan Samarinda Ulu Kalimantan Timur.

Peraturan Daerah (Perda) Daerah Khusus Ibukota (DKI) Jakarta No. 3 Tahun 1992 tentang Penanggulangan Bahaya Kebakaran dalam Wilayah Daerah Khusus Ibukota Jakarta.

Pusdiklatkar. 2006. Modul Pelatihan: Perilaku Api. Jakarta.

Ramli S. 2010. Pedoman Praktis Manajemen Bencana. Jakarta: Dian Rakyat.

Tarwaka, dkk. 2012. Ergonomi untuk Keselamatan Kesehatan Kerja dan Produktivitas. Surakarta: Uniba Press.

Triyono, Agus. 2001. Teknik Penanggulangan Bahaya Kebakaran di Perusahaan. Majalah Hiperkes dan Keselamatan Kerja. Vol. XXXIV (3), Hal. 34-53. 